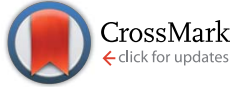

Cite this: RSC Adv., 2016, 6, 51747

\title{
From liquid to thin film: colloidal suspensions for tungsten oxide as an electrode material for Li-ion batteries $\uparrow$
}

\author{
E. J. van den Ham, ${ }^{\text {*a }}$ K. Elen, ${ }^{a}$ I. Kokal, ${ }^{\text {b B. Yağci, }},{ }^{\mathrm{C}}$ N. Peys, ${ }^{a}$ G. Bonneux, ${ }^{a}$ F. Ulu, ${ }^{a}$ \\ W. Marchal, ${ }^{a}$ M. K. Van Bael ${ }^{a}$ and A. Hardy ${ }^{a}$
}

Using a colloidal suspension, tungsten oxide thin films $(150 \mathrm{~nm})$ have been prepared via ultrasonic spray deposition using two different current collectors, namely TiN and Pt. First, the precursor chemistry was studied, revealing that the tungsten present is reduced due to the formation of chlorine gas. Due to a dehydrogenation 1,1-diethoxyethane (DEE) and hydrogen chloride $(\mathrm{HCl})$ evolve from the precursor, reducing the chloride content of the precursor. The thin films were annealed at 400 and $500{ }^{\circ} \mathrm{C}$, yielding tetragonal tungsten oxide without the presence of chlorides. Electrochemical analysis indicated that the TiN current collector has a pronounced positive effect on cycling behavior of the $\mathrm{WO}_{3}$ thin film. A higher annealing temperature yields an improved performance, but annealing at temperatures as low as $400{ }^{\circ} \mathrm{C}$ also yielded electrochemically active $\mathrm{WO}_{3}$. The current study presents a versatile method to produce electrochemically active tungsten oxide thin films with a high volumetric capacity $\left(640 \mathrm{~mA} \mathrm{~h} \mathrm{~cm}^{-3}\right)$ at relatively low temperature to be applied in all-solid-state Li-ion batteries.

Received 5th April 2016

Accepted 20th May 2016

DOI: $10.1039 /$ c6ra08769h

www.rsc.org/advances superiority of LTO as an oxide based negative electrode according to its higher energy density, the $\mathrm{WO}_{3}$ outclasses the LTO according to its volumetric capacity 604 (ref. 20) vs. $228 \mathrm{~mA}$ $\mathrm{h} \mathrm{cm} \mathrm{cm}^{-3}$ (ref. 21 and 22). The volumetric capacity is more applicable for thin film all-solid-state Li-ion batteries since the total battery consists of scaffolding material, current collectors and electrolyte.

In addition, the relative high (de)intercalation voltage between 1.5 and $3 \mathrm{~V}\left(v s \text {. } \mathrm{Li}^{+} / \mathrm{Li}\right)^{8,11,13}$ proves to be very useful when combining $\mathrm{WO}_{3}$ with a solid electrolyte. Indeed, one of the main challenges of the thin film all-solid-state Li-ion batteries $^{22,23}$ is the incorporation of a solid electrolyte. Besides LiPON, ${ }^{24,25}$ Li-ion conducting silicates ${ }^{26,27}$ and few a garnets; ${ }^{28-30}$ thin film solid electrolytes have a limited electrochemical stability at low voltages. ${ }^{1,31}$ Thus the high voltage $\mathrm{WO}_{3}$ negative electrode opens up a broader range of applicable solid electrolyte materials such as perovskite $\mathrm{Li}_{3 x} \mathrm{La}_{(2 / 3)-2 x} \mathrm{TiO}_{3}$ (LLT) ${ }^{32-36}$ and titanium-containing NASICON. ${ }^{37,38}$

Finally, titanium nitride (TiN) is opted as an alternative for the rare and expensive Pt current collector ${ }^{25,34}$ since it combines good electronic conductivity with Li-ion blocking properties. ${ }^{39}$ Unfortunately, TiN tends to oxidize under oxidative annealing conditions. ${ }^{\mathbf{4 0}}$ Here, the potentially low annealing temperature needed for the realization of crystalline $\mathrm{WO}_{3}$ at $300{ }^{\circ} \mathrm{C}$ (ref. 15 and 41 ) prevents TiN oxidation and enables its use as a current collector.

In summary, $\mathrm{WO}_{3}$ is a promising negative electrode worth studying in detail. The current research employs chemical
${ }^{a}$ Hasselt University, Institute for Materials Research, Inorganic and Physical Chemistry and IMEC, Division IMOMEC, Martelarenlaan 42, 3500 Hasselt, Belgium. E-mail: jonathan.vandenham@uhasselt.be

${ }^{b}$ Pavezyum Chemicals, Orhanlı Mah. Ulu Sokak No. 3, 34956 Tuzla, Istanbul, Turkey ${ }^{c}$ Koç University Surface Science and Technology Center (KUYTAM), Rumelifeneri Yolu, Sariyer, 34450, Istanbul, Turkey

$\dagger$ Electronic supplementary information (ESI) available. See DOI: $10.1039 /$ c6ra08769h 
solution deposition ${ }^{15,17,19,42}$ to study $\mathrm{WO}_{3}$ as a potential negative electrode material for all-solid-state Li-ion batteries.

\section{Experimental}

\section{Synthesis of the chlorine-based tungsten precursor}

Tungsten chloride $\left(\mathrm{WCl}_{6}\right.$, Sigma Aldrich, $\left.99.9 \%\right)$ was dissolved in ethanol (ethanol absolute, VWR) and stirred for a 20 minutes, yielding a transparent yellow liquid. Next, water was added until a $1: 1$ water to ethanol volumetric ratio was obtained similar Regragui et al. ${ }^{15}$ resulting in a transparent dark blue liquid (cf. Video S1 $\dagger$ ). The final tungsten concentration in the water/ ethanol solution amounted $10 \mathrm{mM}$.

\section{Deposition on substrates}

TiN (Si coated with $60 \mathrm{~nm}$ of CVD TiN) and Pt (the TiN with an additional $100 \mathrm{~nm}$ sputtered $\mathrm{Pt}$ ) substrates were used in this study. Both substrate types were treated by $\mathrm{UV} / \mathrm{O}_{3}\left(60{ }^{\circ} \mathrm{C}\right.$, $30 \mathrm{~min}$, Novascan PSD Pro Series) prior to the deposition. The precursor solution was deposited onto the substrates via ultrasonic spray deposition (Exacta Coat, Sono-Tek cooperation) using the Accumist nozzle (Sono-Tek cooperation). The deposition temperatures were set at 150,200 and $250{ }^{\circ} \mathrm{C}$. The precursor was dispensed at $0.5 \mathrm{~mL} \mathrm{~min}^{-1}$ and the $\mathrm{N}_{2}$ carrier gas pressure was set at 1.5 psi. The spray nozzle was located $6.9 \mathrm{~cm}$ above the substrate and moved with a speed of $100 \mathrm{~mm} \mathrm{~s}^{-1}$. The spray cycle was repeated 10 times with a waiting time of 5 seconds. After deposition, a sequential hot plate treatment, in static air, was carried out at $300{ }^{\circ} \mathrm{C}(2 \mathrm{~min})$ and at 400 or $500{ }^{\circ} \mathrm{C}$ ( 1 hour). Both $\mathrm{WO}_{3} / \mathrm{TiN}$ and $\mathrm{WO}_{3} / \mathrm{Pt}$ samples received the same thermal treatments and were all stored in an Ar-filled glovebox after the post-deposition anneal.

\section{Characterization - liquid phase}

Ultraviolet-visible spectroscopy was performed on precursor solutions with $1 \mathrm{~mm}$ of tungsten by a Amersham Biosciences Ultrospec 100 pro tool. A Tyndall experiment was performed on the tungsten precursor $(1 \mathrm{~mm})$ using a $35 \mathrm{~mW}$ diode laser (NanoBrook 90Plus). GC-MS was performed on the headspace of the preheated $\left(10 \mathrm{~min}, 70^{\circ} \mathrm{C}\right)$ precursor solution via a Thermo Scientific Trace 1310 GC using a DB5-MS capillary (length $30 \mathrm{~m}$, diameter $0.25 \mathrm{~mm}$ and filter size $0.25 \mu \mathrm{m}$ ); coupled with a Thermo Scientific ISQ LT MS, scanning between 33 and $350 \mathrm{u}$ every 0.2 seconds.

\section{Characterizations - powders}

The thermal decomposition profile of the precursor powder, obtained by drying of the precursor solution at $60{ }^{\circ} \mathrm{C}$, was investigated by thermogravimetric analysis coupled with mass spectroscopy detector (TG-MS, TA instruments Q5000 with Pfeiffer quadrupool MS). $6 \mathrm{mg}$ of the powder was heated in a Pt sample pan, ramped at $10{ }^{\circ} \mathrm{C} \mathrm{min}^{-1}$ from room temperature to $500{ }^{\circ} \mathrm{C}$ in dry air $\left(25 \mathrm{~mL} \mathrm{~min}{ }^{-1}\right)$ and a $\mathrm{N}_{2}$ balance gas $(10 \mathrm{~mL}$ $\left.\min ^{-1}\right)$.

The crystallization process of the precursor powder was studied by high-temperature X-ray diffraction (HT-XRD, Bruker
D8 with an Anton Paar HTK1200 high temperature chamber) from 250 to $900{ }^{\circ} \mathrm{C}\left(10{ }^{\circ} \mathrm{C} \mathrm{min}^{-1}\right)$, in steps of $50{ }^{\circ} \mathrm{C}$ with a counting time of $52.8 \mathrm{~s}$ per step. Transmission electron microscopy (TEM) was performed on a FEI Technai G2 Spirit Twin, operated at $120 \mathrm{kV}$. For this purpose, the precursor solution was sonicated for 2 minutes, small drops were casted onto a carbon coated copper grid (EMS, FCF-200-Cu) and dried under an infrared lamp for 20 minutes.

\section{Characterizations - films}

The morphology of annealed tungsten oxide films was investigated via scanning electron microscopy (SEM, FEI Quanta 200F). The thickness of the films was determined via SEM cross sections, coupled with the density of $\mathrm{WO}_{3}\left(7.15 \mathrm{~g} \mathrm{~cm}^{-3}\right)$ the total amount of deposited $\mathrm{WO}_{3}$ could be determined. The composition of the film was probed by XPS via a Thermo Scientific K-Alpha spectrometer using an aluminum anode (Al $\mathrm{K} \alpha=1468.3 \mathrm{eV}$ ) at an electron take-off angle of $90^{\circ}$ (between the sample surface and the axis of the analyzer lens). The depth-profiling experiment was effected by bombarding 1.000 $\mathrm{eV} \mathrm{Ar}^{+}$ions for 6 levels of $60 \mathrm{~s}$ etching rate. The spectra were recorded using an Avantage 5.9 data system. The binding energy scale was calibrated by assigning the $\mathrm{C} 1 \mathrm{~s}$ signal at $284.5 \mathrm{eV}$. Cyclic voltammetry and charge/discharge measurements were performed with an Autolab PGSTAT128N, using a three electrode setup with a custom made Teflon cell similar to the setup used by Notten et al. ${ }^{39}$ The $\mathrm{WO}_{3} / \mathrm{TiN}$ and $\mathrm{WO}_{3} / \mathrm{Pt}$ samples were used as the working electrode via a copper disc connected to the back of the substrate. Silver paint (Belelux scientific) was used to ensure good conductivity between the copper disc and the substrate. The top of the substrate was accessible to the liquid electrolyte $\left(1.0 \mathrm{M} \mathrm{LiClO}_{4}\right.$ dissolved in polycarbonate, Soulbrain MA) and a Kapton ${ }^{\circledR}$ O-ring was used for sealing. Metallic lithium (99.9\% Sigma Aldrich) served as the counter and reference electrodes. After 3 cycles of CV at 1 $\mathrm{mV} \mathrm{s}^{-1}$ between 1.5 and $4.0 \mathrm{~V}$, charge/discharge measurements were performed between the same cut-off voltages with a constant current of $10 \mu \mathrm{A}(1 \mathrm{C})$. The test cell was operated at $20.0{ }^{\circ} \mathrm{C}$ via a custom made temperature control chamber, inside an Ar-filled glovebox with water an oxygen concentrations $<1 \mathrm{ppm}$. The crystallinity of the films was investigated by XRD via a Bruker D8 equipped with a Lynx eye detector, using a step size of $0.040^{\circ}$ and a counting time of 3 seconds per step at room temperature. Ex situ, post-cycling XRD analysis were performed after 100 cycles for both $\mathrm{WO}_{3} / \mathrm{TiN}$ and $\mathrm{WO}_{3} / \mathrm{Pt}$ samples. After removal from the electrochemical cell, the samples were rinsed with ethanol to remove the organic electrolyte and immediately measured using the stated XRD setup under ambient conditions.

\section{Results and discussion}

\section{Precursor chemistry}

Precursor analysis - the liquid phase. Dissolution of tungsten chloride $\left(\mathrm{WCl}_{6}\right)$ in ethanol leads to a transparent, yellow solution, although the yellow color decays over time. After 
a few days a greenish precipitation was observed. Fig. 1 (red curve) shows that a significant absorption band is present in the UV-A region. The onset of this band is situated on the edge of the visible spectrum, hence the solution exhibits a yellow color. Based on the sample composition and location of the band, it is assigned to dissolved chlorine gas $\left(\mathrm{Cl}_{2}\right){ }^{41,43-46} \mathrm{Fig} .1$ shows that the absorption of this band decreases as a function of time. Indeed, after 90 minutes a colorless liquid is observed. This indicates that the majority of the $\mathrm{Cl}_{2}$ has left the precursor during the first 90 minutes after synthesis. By adding water, a dark blue, transparent liquid is observed and the UV-Vis spectrum shows a significant absorption band between 600 and $780 \mathrm{~nm}$ (Fig. 1). This suggests the reduction of $\mathrm{W}^{6+}$ (ref. 47) and/or forming $\mathrm{WO}_{x}$ agglomerates. Besides light absorption, light scattering of the precursor was observed with a simple Tyndall experiment. This implies that particles are present in the liquid. Fig. 2 shows a TEM image of these particles and indicated the presence of two types of particles: large rod-like particles with 100-150 nm length (Fig. 1) and small circular particles of $20 \mathrm{~nm}$ (Fig. S3†). Therefore, it is assumed that the blue coloration is caused by tungsten oxide agglomerates. This blue color can directly be related to polaron transitions between $\mathrm{W}^{6+} / \mathrm{W}^{5+}$ or $\mathrm{W}^{5+} / \mathrm{W}^{4+},{ }^{4-50}$ or by a bipolaronic transaction based on $\mathrm{W}^{6+} / \mathrm{W}^{4+}{ }^{51}$ This supports the statement that $\mathrm{W}^{6+}$ is reduced in the solution. Note that the rod-like particles are crystalline, as indicated by the electron diffraction (ED) (Fig. 2, inset).

Headspace GC-MS measurements (Table 1) indicate that hydrochloric acid ( $\mathrm{HCl})$ evolves during the dissolution of the tungsten chloride by the presence of a large intensity peak at a retention time of 1.30 minutes. The GC-MS results do not indicate the evolution of $\mathrm{Cl}_{2}$ directly. However, 1,1-diethoxyethane (DEE) was observed at a retention time of 3.66 minutes (Table 1). Assuming that (i) the $\mathrm{Cl}_{2}$ instantaneously reacts with the ethanol matrix, forming acetaldehyde, and (ii) the acetaldehyde instantaneously reacts with the ethanol matrix forming

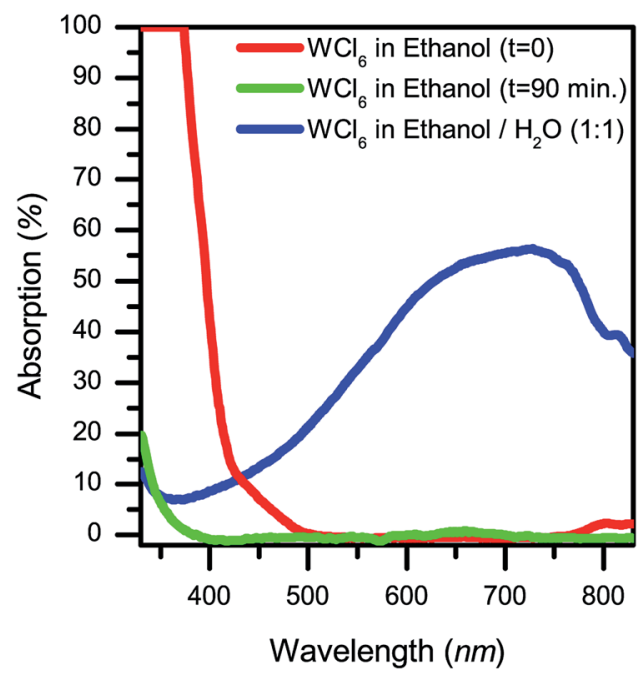

Fig. 1 UV/VIS spectrum of $1 \mathrm{mM} \mathrm{WCl}$ precursors in ethanol and ethanol/water (1: 1) solutions.

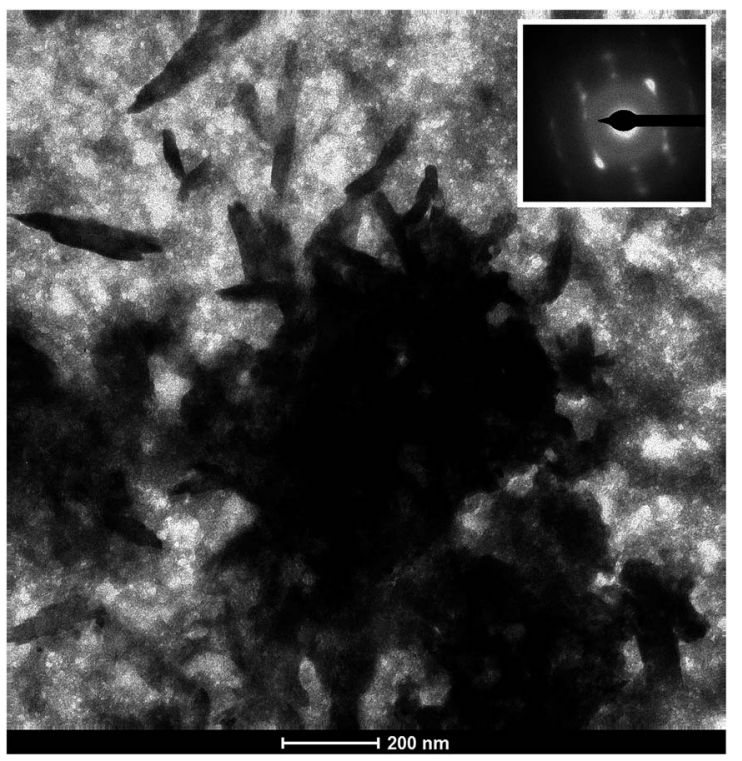

Fig. 2 TEM image of the tungsten precursor deposited on a copper grid and dried before measuring. The inset shows electron diffraction (ED) of a cluster of rod-like particles.

Table 1 Summary of the headspace GCMS results for $\mathrm{WCl}_{6}$ dissolved in ethanol only, as well as the ethanol/water mixture. Details can be found in Fig. S1 and S2

\begin{tabular}{lll}
\hline Product & $\begin{array}{l}\text { Retention time }[\mathrm{min}] \\
\text { ethanol/trace water }\end{array}$ & $\begin{array}{l}\text { Retention time }[\mathrm{min}] \\
\text { ethanol/water } 1: 1 \text { ratio }\end{array}$ \\
\hline $\mathrm{HCl}$ & 1.28 & 1.30 \\
$\mathrm{DEE}$ & 3.67 & 3.66
\end{tabular}

DEE; ${ }^{52,53}$ the observed DEE is explained. The hydrochloric acid, originating from the $\mathrm{WCl}_{6}$ dissolution, fulfills the acidic condition known to catalyze the latter reaction at room temperature..$^{\mathbf{5 3 4}}$

In summary, the following reaction mechanism is proposed:

(i) Chloro-alkoxide substitution shown in eqn (1): ${ }^{\mathbf{4 1}}$

$$
\begin{aligned}
\mathrm{W}^{\mathrm{VI}} \mathrm{Cl}_{6}+x \mathrm{CH}_{3} \mathrm{CH}_{2} \mathrm{OH} \rightleftharpoons \mathrm{W}^{\mathrm{VI}} \mathrm{Cl}_{6-x}\left(\mathrm{CH}_{3} \mathrm{CH}_{2} \mathrm{O}\right)_{x} \\
+x \mathrm{HCl}(1 \leq x \leq 6)
\end{aligned}
$$

(ii) $\mathrm{Cl}_{2}$ formation shown in eqn (2): ${ }^{44}$

$$
\begin{aligned}
2 \mathrm{~W}^{\mathrm{VI}} \mathrm{Cl}_{6-x}\left(\mathrm{CH}_{3} \mathrm{CH}_{2} \mathrm{O}\right)_{x} \rightleftharpoons 2 \mathrm{~W}^{\mathrm{V}} \mathrm{Cl}_{5-x}\left(\mathrm{CH}_{3} \mathrm{CH}_{2} \mathrm{O}\right)_{x} \\
+\mathrm{Cl}_{2}(1 \leq x \leq 5)
\end{aligned}
$$

(iii) Dehydrogenation of ethanol shown in eqn (3): ${ }^{\mathbf{4}}$

$$
\mathrm{Cl}_{2}+\mathrm{CH}_{3} \mathrm{CH}_{2} \mathrm{OH} \rightleftharpoons \mathrm{CH}_{3} \mathrm{CHO}+2 \mathrm{HCl}
$$

(iv) Reaction between acetaldehyde and ethanol to DEE shown in eqn (4): ${ }^{53,54}$

$$
\mathrm{CH}_{3} \mathrm{CHO}+2 \mathrm{CH}_{3} \mathrm{CH}_{2} \mathrm{OH} \rightleftharpoons \mathrm{CH}_{3} \mathrm{CH}\left(\mathrm{OCH}_{2} \mathrm{CH}_{3}\right)_{2}+\mathrm{H}_{2} \mathrm{O}
$$




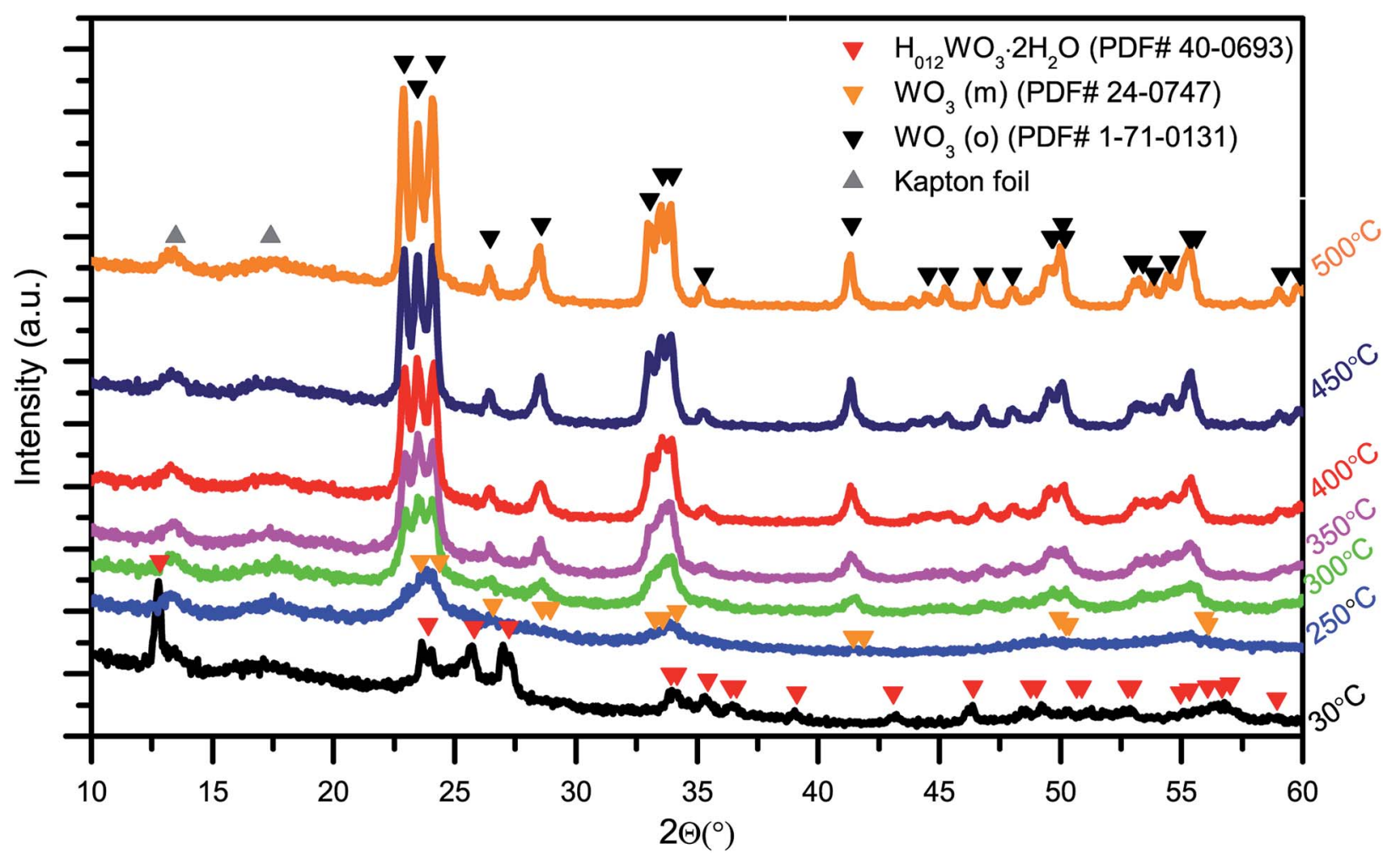

Fig. $3 \mathrm{HT}$-XRD of dried precursor powder, at various temperatures (indicated) in static air.

Precursor analysis - towards oxide formation. The X-ray diffraction of the dried precursor, without any further thermal treatment (Fig. 3), already indicates the presence of the hydrogen tungsten oxide hydrate $\left(\mathrm{H}_{0.12} \mathrm{WO}_{3} \cdot 2 \mathrm{H}_{2} \mathrm{O}\right.$, PDF\# 400693). The presence of this crystal phase supports the (partial) $\mathrm{W}^{6+}$ reduction hypothesis, explaining the blue color of the colloid suspension and of the prepared precursor powder.

Since TEM-ED (Fig. 2, inset and S3, $\dagger$ inset) indicates that only the rod-like particles are crystalline, this crystal phase is assigned to the rod-like particles. This crystalline phase can only be formed by (i) hydrolysis of ethoxy groups into hydroxy groups and (ii) by condensation of the formed hydroxy group with another hydroxy or ethoxy group into an oxygen bridge between two tungsten ions. ${ }^{55,56}$

Heating the dried precursor powder reveals a transition to monoclinic $\mathrm{WO}_{3}$ (PDF\# 24-0747) already at $300{ }^{\circ} \mathrm{C}$ in Fig. 3. Though a shift of XRD peaks to lower $2 \theta$ values is expected based on thermal expansion (e.g. the (112) peak of the orthorhombic phase at $28.0^{\circ}$ ), a more pronounced shift is observed for the (222) and (400) peaks of the monoclinic phase, at 41.9 and $50.0^{\circ}$ respectively. This indicates a phase transition from the monoclinic to orthorhombic $\mathrm{WO}_{3}$ (PDF\# 1-71-0131). Although both phases are difficult to differentiate, this temperature-dependent phase transition was reported previously in detail. ${ }^{57,58}$

To further study the changes occurring during heating, TGMS was carried out on the dried precursor (Fig. 4). The MS only indicates the evolution of water: $\mathrm{OH}^{+}(\mathrm{m} / z=17)$ and $\mathrm{H}_{2} \mathrm{O}^{+}$ $(m / z=18)$. This evolution is separated in two steps: around 65 and $225{ }^{\circ} \mathrm{C}$. Combined with the results gained from the HT-XRD (Fig. 3), the first weight loss at $65^{\circ} \mathrm{C}$ is attributed to evaporation of residual (free) water. The second weight loss at $225{ }^{\circ} \mathrm{C}$ is assigned to the release of crystal water. The last step only accounts for $6 \mathrm{wt} \%$ of the total weight loss, revealing that the majority of the sample contains amorphous phases. A fully crystallized sample (i.e. $\mathrm{H}_{0.12} \mathrm{WO}_{3} \cdot 2 \mathrm{H}_{2} \mathrm{O}$ ) would lead to the removal of crystal water with a weight loss of approximately $13 \mathrm{wt} \%$.

Since no evolution of chlorides is found during the thermal treatment, the hypothesis that the chlorides leave the system during precursor synthesis is further confirmed. The total weight loss of $8 \mathrm{wt} \%$ during the thermal treatment up to $500{ }^{\circ} \mathrm{C}$ is a beneficial precursor property regarding film formation since less shrinkage and densification is to be expected leading to less cracks in the final film. ${ }^{59}$

In summary the following insights regarding the tungsten precursor chemistry are obtained:

(1) A part of the $\mathrm{W}^{6+}$ originating from the $\mathrm{WCl}_{6}$ source is reduced to $\mathrm{W}^{5+}$ or $\mathrm{W}^{4+}$ via the evolution of $\mathrm{HCl}$ and $\mathrm{DEE}$ from the liquid phase;

(2) Water causes hydrolysis and condensation reactions leading to a colloidal suspension containing crystalline particles;

(3) The precursor powder releases a very small amount of water $(8 \mathrm{wt} \%)$ during thermal treatment which will be beneficial for the film formation. 


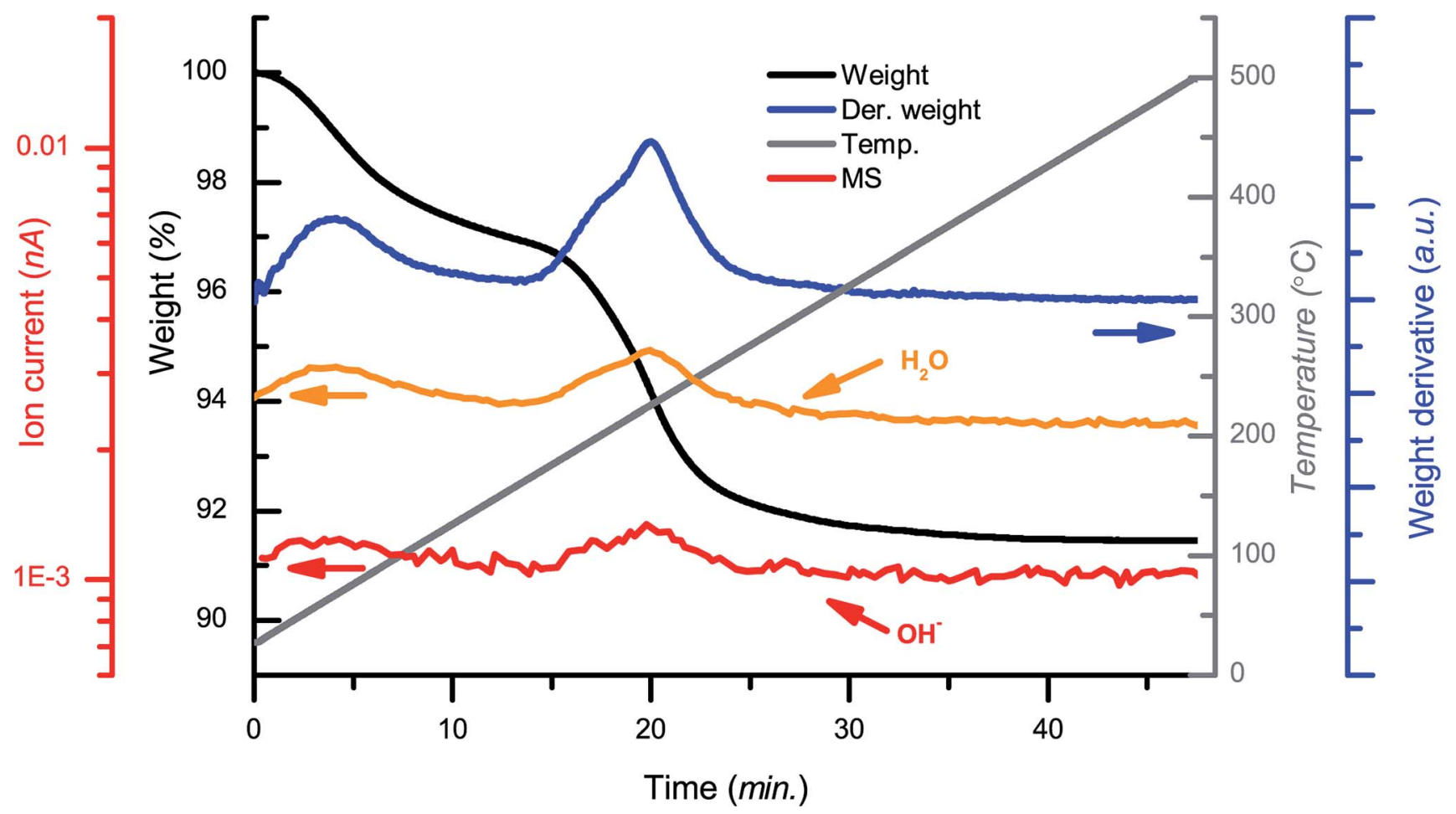

Fig. 4 TGA-MS of dried tungsten precursor, during heating to $500{ }^{\circ} \mathrm{C}$ at $10{ }^{\circ} \mathrm{C} \mathrm{min}^{-1}$ in dry air.

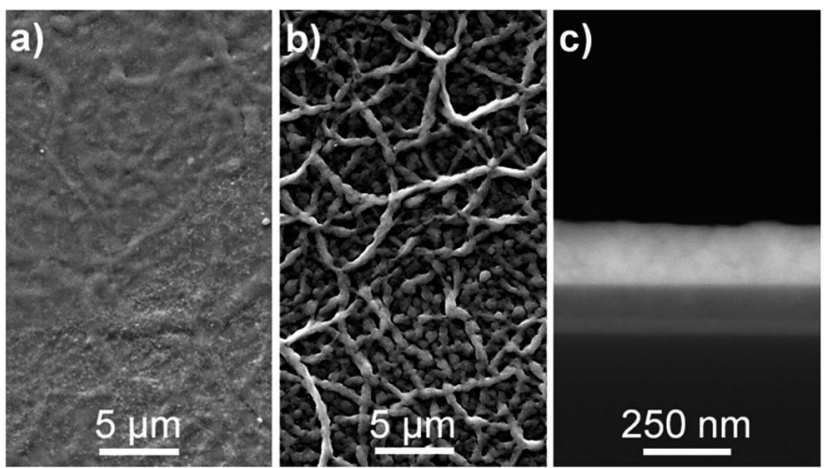

Fig. 5 SEM images of $\mathrm{WO}_{3}$ coated TiN substrate. Top view images are shown for (a) $\mathrm{TiN}$ at $150{ }^{\circ} \mathrm{C}$, (b) TiN at $200^{\circ} \mathrm{C}$. A cross section using back-scattered imaging is shown in (c) for TiN at $150{ }^{\circ} \mathrm{C}$. All samples were annealed at $500^{\circ} \mathrm{C}$ in static air after deposition.

\section{Tungsten oxide thin films}

Film morphology. (Cross-sectional) SEM was used to visualize the films' morphology and thickness (Fig. 5). Whereas the surface of the thin film deposited at $150{ }^{\circ} \mathrm{C}$ is relatively smooth (Fig. 5a and c), the surface looks rather rough while increasing the deposition temperature to $200{ }^{\circ} \mathrm{C}$ (Fig. 4b). After the deposition at $250{ }^{\circ} \mathrm{C}$, no material is present on the substrate (not shown). These observations are in agreement with the film formation mechanism proposed by Perednis et al. ${ }^{60}$ As the deposition temperature increases, the size of precursor droplets decreases due to an increased solvent evaporation. In an extreme case (here $250{ }^{\circ} \mathrm{C}$ ), the droplets are converted to powders before hitting the substrate, resulting in the deposition of particles with a poor substrate adhesion.

However, this film formation mechanism does not explain the difference in morphology as observed between the deposition temperatures of 150 and $200{ }^{\circ} \mathrm{C}$, respectively resulting in a smooth or rough surface. It is proposed that a lower deposition temperature (i.e. $150^{\circ} \mathrm{C}$ ) leads to a lower solvent evaporation rate allowing for coalescence ${ }^{61}$ to occur for the particles present in the sprayed suspension after hitting the substrate surface, hence leading to a smooth surface. Here, 10 deposition cycles result in a film thickness of about $150 \mathrm{~nm}$ (Fig. 5c). A higher deposition temperature $\left(200{ }^{\circ} \mathrm{C}\right)$ causes a fast solvent evaporating inhibiting particle coalescence and leading the root-like surface morphology.

Film composition and phase formation. As discussed previously, the precursor study indicated that most of the chlorides are leaving the precursor in the liquid phase. This is confirmed by XPS measurements performed on thin films, which do not show any signs of chlorides ( $c f$. Fig. S8 and S9†). Regarding the oxidation state of tungsten, the XPS spectrum of $\mathrm{W} 4 \mathrm{f}(1 \mathrm{a})$ resulted in doublets of $4 \mathrm{f}_{7 / 2}$ at $37.6 \mathrm{eV}$ and $4 \mathrm{f}_{5 / 2}$ at $35.2 \mathrm{eV}$ (Fig. 6). These energy positions correspond to the valence state of $\mathrm{W}^{6+} .{ }^{15,62,63}$ This implies that the oxidative anneal applied after deposition oxidizes the $\mathrm{W}^{5+}$ present in the precursor. Finally, the XPS spectrum of O 1s (Fig. S6†) with a binding energy at $530.3 \mathrm{eV}$ was assigned to $\mathrm{O}^{2-}$ that form strong $\mathrm{W}-\mathrm{O}$ bonds. ${ }^{64}$ No difference in film composition was found while changing the substrate from TiN to Pt (cf. Fig. S4S9†). To probe more than just the top, surface etching was performed. As was the case for the top surface, no chlorides were detected deeper inside of the layer (Fig. S8 $\dagger$ ). However, due 


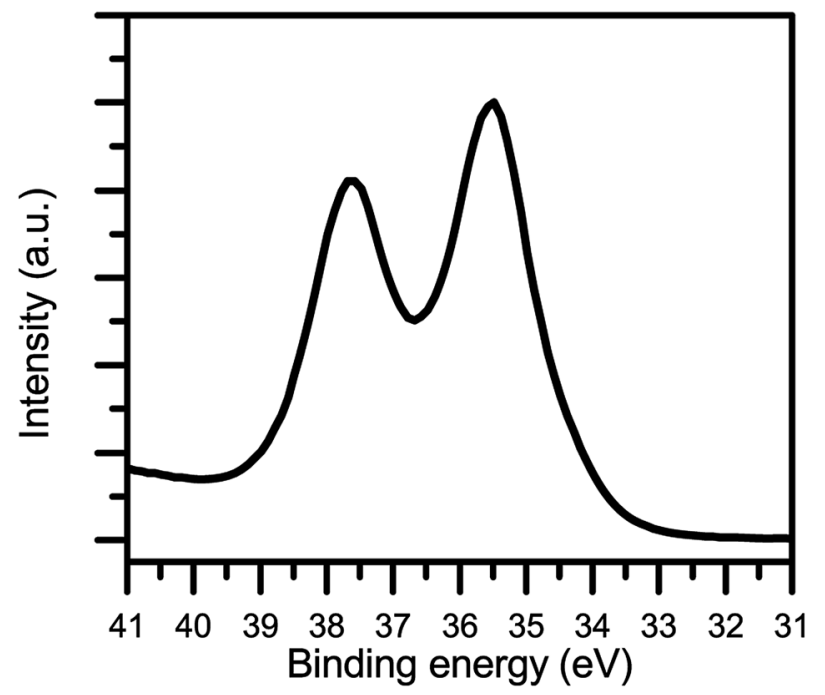

Fig. 6 W $4 \mathrm{f} \mathrm{XPS} \mathrm{spectrum} \mathrm{of} \mathrm{WO}_{3}$ films annealed at $500{ }^{\circ} \mathrm{C}$ for 1 hour (static air) on TiN.

to the fact that $\mathrm{Ar}^{+}$was used for etching, no conclusions could be drawn regarding the oxidation state of the tungsten present (Fig. S4†). It is known that a high energy etching tool, $\mathrm{Ar}^{+}$ etching reduces metal ions, especially in case of tungsten. ${ }^{\mathbf{4 8 , 6 5}}$

Although the XPS measurements regarding tungsten were restricted to surface analysis, cyclic voltammetry (CV), probing a larger volume of the $\mathrm{WO}_{3}$ films, also confirmed the presence of $\mathrm{W}^{6+}$ (Fig. 7), as $\mathrm{W}^{6+}$ and $\mathrm{W}^{5+}$ can be discriminated based on their reduction potentials. ${ }^{51,66} \mathrm{~A}$ first reduction peak at $2.67 \mathrm{~V}$ can be related to the reduction of $\mathrm{W}^{6+}$ to $\mathrm{W}^{5+}$ (indicated by 1 in Fig. 7), the second reduction at $2.38 \mathrm{~V}$ corresponds to the consecutive $\mathrm{W}^{5+}$ to $\mathrm{W}^{4+}$ reduction ${ }^{51}$ (indicated by 2 in Fig. 7). In accordance with XPS, cyclic voltammetry confirms that $\mathrm{W}^{6+}$ is

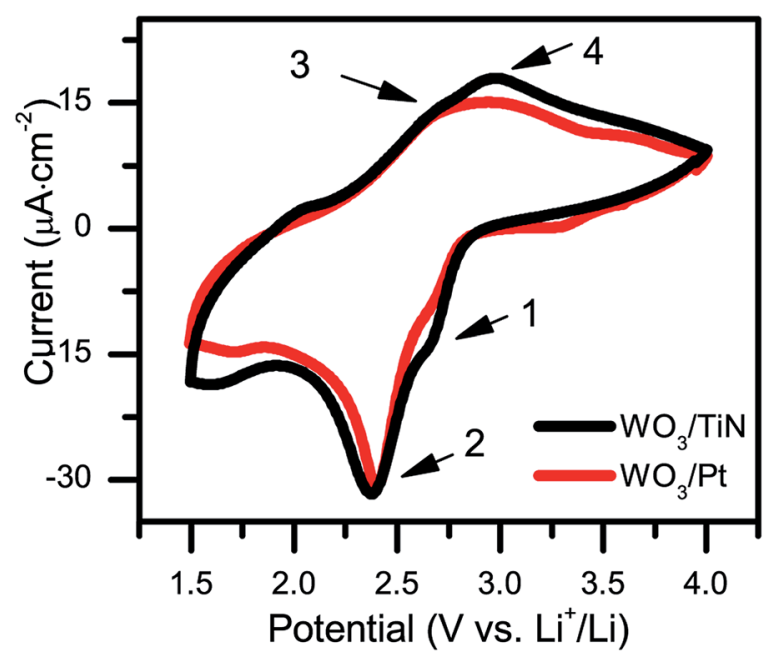

Fig. 7 Cyclic voltammogram of 10 layers of $\mathrm{WO}_{3}$ deposited on $\mathrm{TiN}$ (black) and Pt (red), measured at $1 \mathrm{mV} \mathrm{s}^{-1}$ in $1 \mathrm{M} \mathrm{LiClO}_{4}$ in PC. The films were submitted to a post deposition anneal of 1 hour at $500{ }^{\circ} \mathrm{C}$ in static air. The numbers indicate the reduction and oxidation reactions occurring: (1) $\mathrm{W}^{6+} \rightarrow \mathrm{W}^{5+}$, (2) $\mathrm{W}^{5+} \rightarrow \mathrm{W}^{4+}$, (3) $\mathrm{W}^{4+} \rightarrow \mathrm{W}^{5+}$ and (4) $\mathrm{W}^{5+} \rightarrow \mathrm{W}^{6+}$. present in the films. The fact that the $\mathrm{W}^{5+}$ to $\mathrm{W}^{4+}$ reduction occurs does not mean $\mathrm{W}^{5+}$ is present in the pristine film as this reaction takes place after the $\mathrm{W}^{6+}$ to $\mathrm{W}^{5+}$ reduction, yielding an overall $\mathrm{W}^{6+}$ to $\mathrm{W}^{4+}$ reduction.

XRD measurements on the films deposited on the two different substrates both indicate the presence of tetragonal $\mathrm{WO}_{3}$ phase (Fig. 8, bottom), for which $\mathrm{W}^{6+}$ is required. The tetragonal phase was identified, especially because of the double peak in the $22-24^{\circ}$ region. Three peaks would be observed in case of monoclinic or orthorhombic phases and only a single peak for the cubic phase of $\mathrm{WO}_{3}$. In both cases the substrates peaks of TiN and Pt were identified. For Pt, this is expected since this metal is inert in the used annealing conditions. The presence of TiN is less obvious as TiN tends to oxidize to form $\mathrm{TiO}_{2}$ while annealing in oxidative conditions. ${ }^{40}$ Since at least part of the tungsten is reduced as-deposited, it might act as a protection to prevent (partial) oxidation of the TiN. However, $\mathrm{CV}$ of $\mathrm{WO}_{3}$ on TiN (Fig. 7, left) shows small reduction and oxidation peaks at 1.6 and $2.0 \mathrm{~V}$, respectively. This suggest that a fraction of TiN is oxidized during annealing at $500{ }^{\circ} \mathrm{C}$, yielding $\mathrm{TiO}_{2}{ }^{67}$ This leads to a possible lower conductivity of the TiN current collector. Notably, both films have a different crystal structure than the powders annealed at the same temperature. The tetragonal phase normally exists at temperatures above $700{ }^{\circ} \mathrm{C}$ (ref. 57 and 58) or by insertion of alkali ions. ${ }^{68,69}$ Since both are not the case, it is thought that the substrate favors the formation of the tetragonal phase at a lower annealing temperature $\left(500{ }^{\circ} \mathrm{C}\right)$ and remains stable at room temperature.

\section{Electrochemical analysis}

The presence of $\mathrm{W}^{6+}$ was probed with cyclic voltammetry as was discussed above. While inserting lithium into the crystal structure, the tungsten is reduced. This is shown in eqn (5).

$$
\mathrm{WO}_{3}+x \mathrm{Li}+x \mathrm{e}^{-} \rightleftharpoons \mathrm{Li}_{x} \mathrm{WO}_{3}
$$

The CV (Fig. 7) shows that this reaction is not limited to $\mathrm{W}^{5+}$, but $\mathrm{W}^{4+}$ is also present as was previously shown. In Fig. 7, two oxidation peaks can be observed which are associated to the $\mathrm{W}^{4+}$ to $\mathrm{W}^{5+}$ and $\mathrm{W}^{5+}$ to $\mathrm{W}^{6+}$ (indicated by 3 and 4 in Fig. 7 , respectively). The results are summarized in Table 2 . In case of TiN a slightly larger overpotential is measured compared to Pt, especially in the case of the $\mathrm{W}^{5+}$ to $\mathrm{W}^{4+}$. This is probably due to larger resistance of the substrate, as part of the TiN is oxidized during the annealing. Significant differences are found between the type of substrates while comparing the peaks of the $\mathrm{W}^{5+}$ oxidation peak, as indicated by 4 in Fig. 7. Especially in the case of Pt the oxidation peaks have a relatively low intensity, indicating that part of the tungsten present is irreversibly reduced with Pt as a substrate.

Overall the charge/discharge measurements of $\mathrm{WO}_{3}$ on TiN and Pt look comparable (Fig. 9), some differences will be discussed in the next paragraph. In general, for both substrates a first small voltage plateau is found at $2.7 \mathrm{~V}$, which is assigned to the intercalation of $\mathrm{Li}^{+}$into the tetragonal phase. ${ }^{\mathbf{6 8 9}} \mathrm{A}$ second, large plateau is found between 2.6 and $2.4 \mathrm{~V}$, which is related to $\mathrm{Li}^{+}$insertion in the cubic phase. This phase is formed 


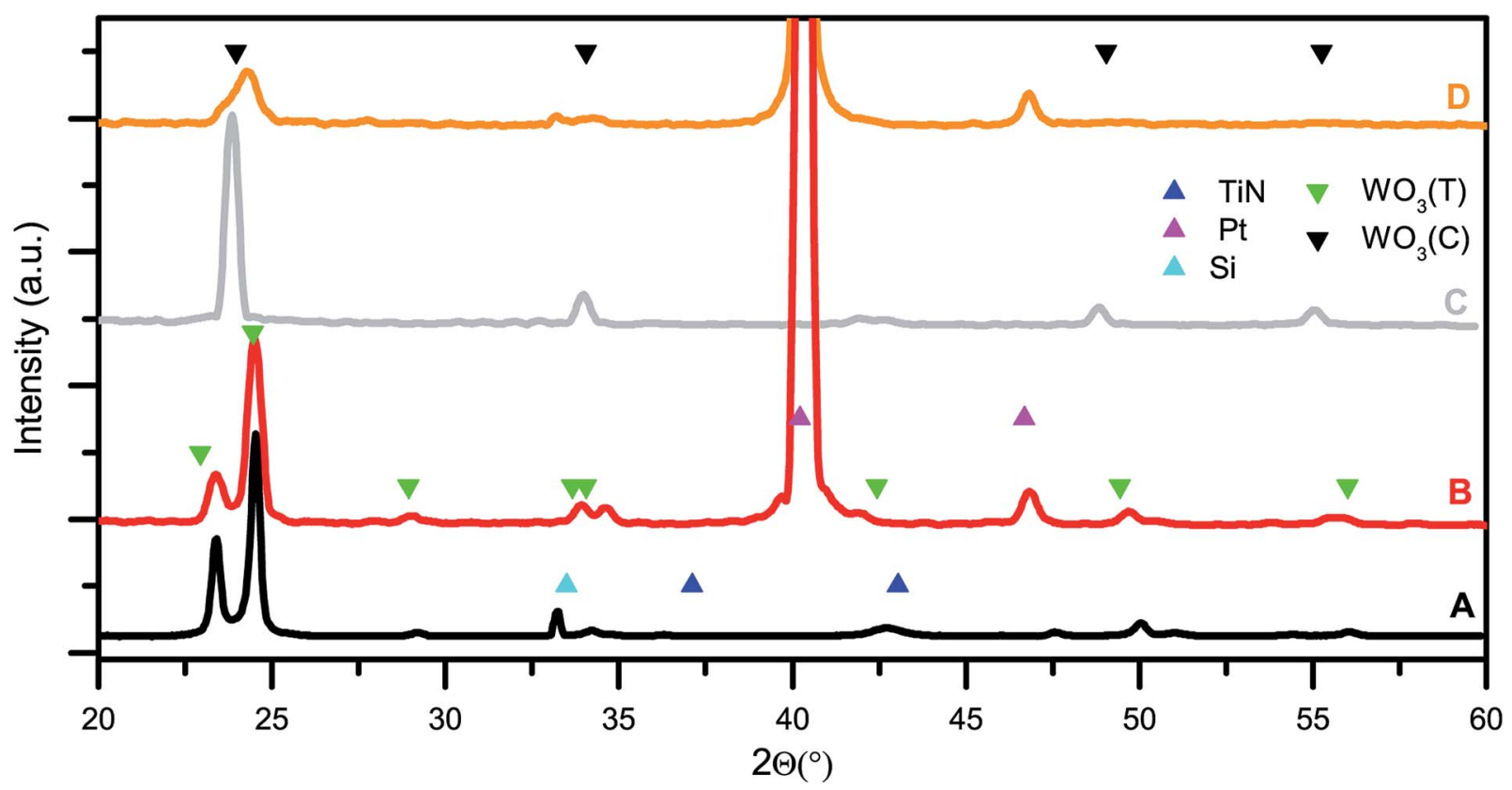

Fig. 8 XRD of 10 layers of $\mathrm{WO}_{3}$ deposited, deposited at $150^{\circ} \mathrm{C}$. The films were submitted to a post deposition anneal of 1 hour at $500{ }^{\circ} \mathrm{C}$ in static air. Pristine $\mathrm{WO}_{3}$ on TiN (A) and Pt (B), as compared to $\mathrm{WO}_{3}$ after 100 cycles of charge/discharge at $1 \mathrm{C}$ on TiN (C) and Pt (D). References indicated as followed: TiN ( $\Delta$ JCPDS 01-87-0632), Pt ( $\Delta$ JCPDS 01-87-0647), Si ( $\Delta$ JCPDS 01-72-1088), tetragonal WO ${ }_{3}(\nabla$ JCPDS 01-85-807) and cubic $\mathrm{WO}_{3}(\boldsymbol{\nabla}$ JCPDS 20-1323).

Table 2 Peak potentials measured by cyclic voltammetry of 10 layers of $\mathrm{WO}_{3}$ deposited on TiN and Pt, measured at $1 \mathrm{mV} \mathrm{s}^{-1}$ in $1 \mathrm{M} \mathrm{LiClO}_{4}$ in $\mathrm{PC}$. The films were submitted to a post deposition anneal of 1 hour at $500{ }^{\circ} \mathrm{C}$ in static air

\begin{tabular}{llll}
\hline Substrate & Reaction & $\begin{array}{l}\text { Reduction } \\
\text { potential }[\mathrm{V}]\end{array}$ & $\begin{array}{l}\text { Oxidation } \\
\text { potential [V] }\end{array}$ \\
\hline TiN & $\mathrm{W}^{6+}+\mathrm{e}^{-} \leftrightarrow \mathrm{W}^{5+}$ & 2.67 & 2.97 \\
Pt & $\mathrm{W}^{6+}+\mathrm{e}^{-} \leftrightarrow \mathrm{W}^{5+}$ & 2.67 & 2.96 \\
TiN & $\mathrm{W}^{5+}+\mathrm{e}^{-} \leftrightarrow \mathrm{W}^{4+}$ & 2.38 & 2.68 \\
Pt & $\mathrm{W}^{5+}+\mathrm{e}^{-} \leftrightarrow \mathrm{W}^{4+}$ & 2.40 & 2.68
\end{tabular}

upon sufficient lithiation $\left(x>0.13\right.$ for $\left.\mathrm{Li}_{x} \mathrm{WO}_{3}\right)$ of the tetragonal phase.$^{68,69}$ Finally, a considerable amount of charge is inserted while maintaining a slight slope (i.e. without clearly defined voltage plateau), which suggests that amorphous phases are responsible for a considerable part of the total capacity. ${ }^{69}$ The amorphous $\mathrm{WO}_{3}$ is known to have a wide distribution of site energies, yielding a poorly defined voltage plateau. ${ }^{\mathbf{1 6}}$ The capacity fading observed during the cause of 100 charge/ discharge cycles for both $\mathrm{WO}_{3} / \mathrm{TiN}$ and $\mathrm{WO}_{3} / \mathrm{Pt}$ seems to be related to the destruction or irreversible lithiation of the cubic phase, as the voltage plateau between 2.6 and $2.4 \mathrm{~V}$ (lithiation) shortens significantly.

As was mentioned before, there are small differences while comparing the charge/discharge curves of the two substrates in Fig. 9a. First of all the capacity fading (comparing the first and hundredth cycle) is more severe for $\mathrm{WO}_{3}$ on Pt. While referring back to the cyclic voltammetry measurements (Fig. 7), the stronger capacity fading in case of $\mathrm{WO}_{3} / \mathrm{Pt}$ as compared to $\mathrm{WO}_{3} / \mathrm{TiN}$ is related to irreversible reduction of the tungsten present. In addition, the voltage plateaus of both the tetragonal and cubic phases are significantly shorter in case of Pt. This means that less tetragonal and cubic phase is available for Li insertion. Finally, the voltage slope before cut-off, previously assigned to disordered or amorphous $\mathrm{WO}_{3}$, is significantly longer in case of Pt. All these arguments suggest a less crystalline material is available for lithiation on $\mathrm{Pt}$ compared to TiN.

(Ex situ) XRD performed on cycled films (Fig. 8, top) yield another clue what the main differences between the two substrates are. For $\mathrm{WO}_{3}$ on TiN, a clear transition from tetragonal to cubic $\mathrm{WO}_{3}$ can be observed upon cycling. However, in case of Pt a difference is noted. In the first place the crystallinity is significantly lower, as the peaks at 24 and $33.5^{\circ}$ are much broader. In addition, the (100) peak at $24^{\circ}$ is significantly shifted to the right as to compared to TiN as substrate; combined with a small peak at $34^{\circ}$ this might imply that a mixture of cubic and predominantly tetragonal phase is present.

The poor performance of Pt as substrate is expressed as well in the charge/discharge measurements as function of cycle number (Fig. 9b). Although the overall capacity of $\mathrm{WO}_{3}$ on TiN and Pt seems comparable at first, in case of Pt the delithiation capacity drops to a significant lower level from the $5^{\text {th }}$ cycle and onward. While $\mathrm{WO}_{3}$ on TiN leads to a steady coulombic efficiency of $99.2 \%$, in case of Pt much more variation is observed with a maximum efficiency of $96.6 \%$, although both samples were submitted to the same synthesis conditions and anneals. The capacity of the $\mathrm{WO}_{3} / \mathrm{TiN}$ films surpasses the theoretical value of $0.75 \mathrm{Li}$ per $\mathrm{WO}_{3}$ unit for the cubic phase, ${ }^{69}$ although Fig. 9b shows that after 100 cycles a more stable capacity value 
a)

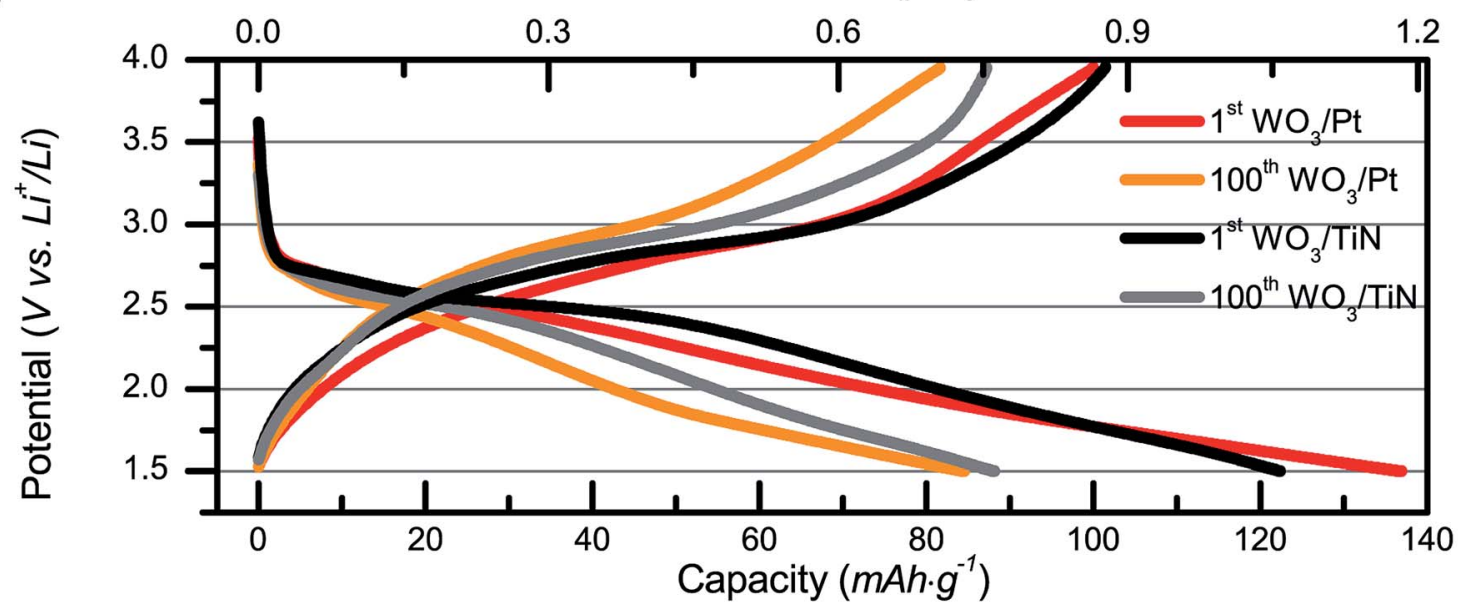

b)

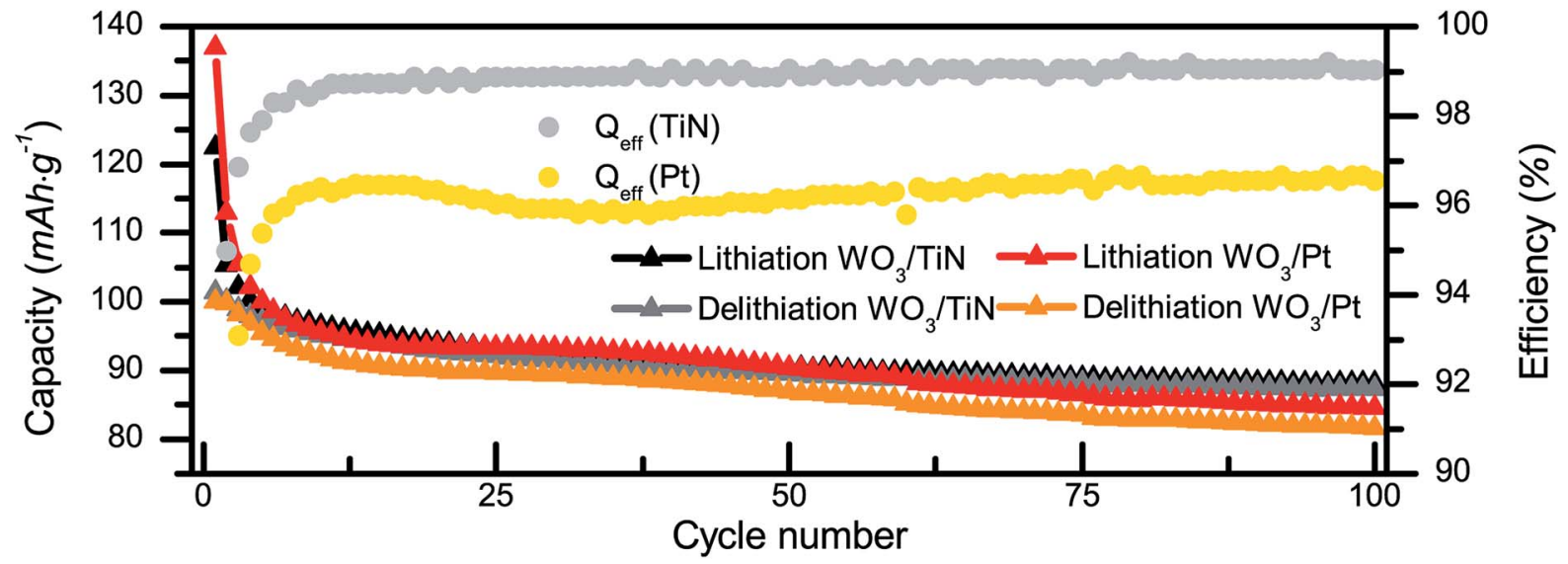

Fig. 9 Charge/discharge curves of 10 layers of $\mathrm{WO}_{3}$ deposited on $\mathrm{TiN}$ and annealed at $500{ }^{\circ} \mathrm{C}$ for 1 hour in static air, measured at $1 \mathrm{C}$ in $1.0 \mathrm{M}$ $\mathrm{LiClO}_{4}$ at $20^{\circ} \mathrm{C}$. (a) shows capacity/potential curves and (b) shows capacity and coulombic efficiency versus cycle number.

close to the theoretical maximum is reached. Very low coulombic efficiencies are registered the first cycles (starting from 82.8 and $73.1 \%$ for TiN and Pt, respectively), the capacity values surpassing theoretical values are therefore attributed to irreversible intercalation into amorphous phases as observed in the slope before cut-off noted previously (Fig. 9a). The capacity values reached are however equal to $\mathrm{WO}_{3}$ in bulk (powder) form using a comparable voltage range,$^{20}$ indicating that at least in case of TiN as substrate sufficient crystallinity and phase stability is reached.

In view of device integration and oxidation of $\mathrm{TiN}$ into $\mathrm{TiO}_{2}$, lower temperature annealing temperatures were investigated by charge/discharge measurements. $300{ }^{\circ} \mathrm{C}$ appeared to be too low to yield electrochemically active material (not shown). After 1 hour at $300{ }^{\circ} \mathrm{C}$ not all the (crystal) water has left the system yet (Fig. 3), which might be an indicator for inactivity. Another explanation might be that bleaching, i.e. oxidation to tungsten from either $\mathrm{W}^{4+}$ or $\mathrm{W}^{5+}$, occurs so slowly that tungsten oxide phases are insufficiently formed. It was reported previously that bleaching by thermal annealing of tungsten oxide films occurs at much lower speeds at $400^{\circ} \mathrm{C}$ as compared to $500{ }^{\circ} \mathrm{C}$ in oxygen rich conditions.$^{48}$ Nevertheless, at $400{ }^{\circ} \mathrm{C}$ electrochemically active films were indeed obtained ( $c f$.
Fig. S10†), although activity was significantly lower as compared to the $500{ }^{\circ} \mathrm{C}$ case for both $\mathrm{WO}_{3} / \mathrm{TiN}$ and $\mathrm{WO}_{3} / \mathrm{Pt}$ samples. This matches with the bleaching behavior at these temperatures. ${ }^{48}$ However, after 100 cycles part of the Pt is visible macroscopically (not shown). This implies that due to cycling $\mathrm{WO}_{3}$ on Pt, structural changes appear as was the case for the $500{ }^{\circ} \mathrm{C}$ anneal (Fig. 9). However, in case of the $400{ }^{\circ} \mathrm{C}$ anneal the effect seems to be more severe. Regarding adhesion in case of Pt as substrate, the film appeared to be more stable after an anneal at $500{ }^{\circ} \mathrm{C}$ as compared $400{ }^{\circ} \mathrm{C}$. In both cases there is a drop in efficiency and capacity followed by a slight improvement between 20 and 40 cycles, it is therefore thought that the same physical process acts on the $\mathrm{WO}_{3} / \mathrm{Pt}$ combination which is intensified at lower annealing temperatures. Adhesion of the $\mathrm{WO}_{3}$ film to TiN is therefore regarded significantly better as compared to Pt. Nevertheless, the overall performance of $\mathrm{WO}_{3} / \mathrm{TiN}$ at $400{ }^{\circ} \mathrm{C}$ (coulombic efficiency $99.0 \%$, capacity of $75 \mathrm{~mA} \mathrm{~h} \mathrm{~g}^{-1}, c f$. Fig. S10 $\dagger$ ) are lower than the same $\mathrm{WO}_{3} / \mathrm{TiN}$ combination annealed at $500{ }^{\circ} \mathrm{C}$ (Fig. 9). These differences are ascribed to better crystallization induced by improved bleaching ${ }^{48}$ and/or increase of oxygen vacancies ${ }^{20}$ at higher annealing temperatures. 


\section{Conclusions}

The chemistry of tungsten chloride in an ethanol/water mixture was explored for the synthesis of tungsten oxide films starting from a tungsten chloride-based solution. Part of the tungsten present in the precursor was reduced while forming chlorine gas and 1,1-diethoxyethane. The chlorine leaves the precursor as hydrogen chloride gas leading to a chlorine depleted precursor. In addition, via hydrolysis and condensation, particles were formed resulting in a colloidal suspension. Via ultrasonic spray deposition of the colloidal suspension and a subsequent oxidative annealing at $500{ }^{\circ} \mathrm{C}$, electrochemically active thin films were obtained with a capacity value of $90 \mathrm{~mA} \mathrm{~h}$ $\mathrm{g}^{-1}$ or $640 \mathrm{~mA} \mathrm{~h} \mathrm{~cm}^{-3}$. A clear difference in the performance was noted between the TiN and Pt substrate. The TiN allows a higher coulombic efficiency and a much more stable capacity evolution, especially in the case of an annealing temperature as low as $400{ }^{\circ} \mathrm{C}$. The relative low annealing temperature required for the formation of active tungsten oxide thin films is an important breakthrough allowing the use of TiN as low-cost alternative for the Pt current collector. In addition, this approach opens up new possibilities for the fabrication of all-solid-state Li-ion batteries as these $\mathrm{WO}_{3}$ films, exhibiting a high volumetric capacity, can be combined with electrochemically instable solid electrolytes such as $\mathrm{Li}_{3 x} \mathrm{La}_{(2 / 3)-2 x} \mathrm{TiO}_{3}$. Arguably, the significant loss of power density expected for an all-solidstate Li-ion battery - caused by the relative high intercalation voltage the of the proposed $\mathrm{WO}_{3}$ films - is compensated by the (i) compatibility with several (oxide-based) solid-state electrolytes, (ii) ease of processing and (iii) relative low temperature requirements. As the proposed route is a low cost method in combination with inexpensive materials, ultrasonic spray deposition of $\mathrm{WO}_{3}$ colloidal suspensions is a promising method for upscaling purposes. This further underlines the significance of this versatile synthesis method.

\section{Acknowledgements}

The authors thank Jan Czech for performing the headspace GCMS measurements, Giulia Maino for the helpful discussion regarding the electrochemical measurements and Prof. Jan D'Haen for discussing XRD data. Imec (Leuven, Belgium) and the CoCooN research group Ghent University (Belgium) are acknowledged for providing substrates. The Energy Materials and Devices group of Eindhoven University of Technology is acknowledged for assistance regarding the electrochemical measurements. This study was partially supported by the IWT SOS Lion project.

\section{Notes and references}

1 P. Knauth, Solid State Ionics, 2009, 180, 911-916.

2 K. Takada, Acta Mater., 2013, 61, 759-770.

3 V. Thangadurai and W. Weppner, Ionics, 2006, 12, 81-92.

4 J. B. Bates, N. J. Dudney, B. Neudecker, A. Ueda and C. D. Evans, Solid State Ionics, 2000, 135, 33-45.
5 D. Pinzaru and V. Thangadurai, J. Electrochem. Soc., 2014, 161, A2060-A2067.

6 M. Roeder, A. B. Beleke, U. Guntow, J. Buensow, A. Guerfi, U. Posset, H. Lorrmann, K. Zaghib and G. Sextl, J. Power Sources, 2016, 301, 35-40.

7 S. Y. Tsai, K. Z. Fung and C. T. Ni, ECS Trans., 2015, 68, 3743.

8 W.-J. Li and Z.-W. Fu, Appl. Surf. Sci., 2010, 256, 2447-2452.

9 D. G. Barton, S. L. Soled and E. Iglesia, Top. Catal., 1998, 6, 87-99.

10 C. Di Valentin, F. Wang and G. Pacchioni, Top. Catal., 2013, 56, 1404-1419.

11 J. P. Perereira-Ramos, R. Baddour-Hadjean, N. Kumagai and K. Tanno, Electrochim. Acta, 1993, 38, 431-436.

12 K. Huang and Q. Zhang, Nano Energy, 2012, 1, 172-175.

13 A. Yu, N. Kumagai, Z. Liu and J. Y. Lee, J. Solid State Electrochem., 1998, 2, 394-400.

14 G. A. Niklasson and C. G. Granqvist, J. Mater. Chem., 2007, 17, 127-156.

15 M. Regragui, M. Addou, A. Outzourhit, J. C. Bernede, E. El Idrissi, E. Benseddik and A. Kachouane, Thin Solid Films, 2000, 358, 40-45.

16 J. Garciacanadas, Solid State Ionics, 2004, 175, 521-525.

17 K. Nishio, T. Sei and T. Tsuchiya, J. Ceram. Soc. Jpn., 1999, 107, 199-203.

18 C. Guo, S. Yin, M. Yan, M. Kobayashi, M. Kakihana and T. Sato, Inorg. Chem., 2012, 51, 4763-4771.

19 J. Denayer, P. Aubry, G. Bister, G. Spronck, P. Colson, B. Vertruyen, V. Lardot, F. Cambier, C. Henrist and R. Cloots, Sol. Energy Mater. Sol. Cells, 2014, 130, 623-628.

20 W. Li, A. Sasaki, H. Oozu, K. Aoki, K. Kakushima, Y. Kataoka, A. Nishiyama, N. Sugii, H. Wakabayashi, K. Tsutsui, K. Natori and H. Iwai, Microelectron. Reliab., 2015, 55, 402-406.

21 P. V Braun, J. Cho, J. H. Pikul, W. P. King and H. Zhang, Curr. Opin. Solid State Mater. Sci., 2012, 16, 186-198.

22 J. F. M. Oudenhoven, L. Baggetto and P. H. L. Notten, Adv. Energy Mater., 2011, 1, 10-33.

23 P. H. L. Notten, F. Roozeboom, R. A. H. Niessen and L. Baggetto, Adv. Mater., 2007, 19, 4564-4567.

24 J. B. Bates, N. J. Dudney, G. R. Gruzalski, R. A. Zuhr and A. Choudhury, J. Power Sources, 1993, 44, 103-110.

25 H. I. Schlesinger, H. C. Brown, A. E. Finholt, X. Y. J. B. Bates, G. E. Jellison and F. X. Hart, J. Electrochem. Soc., 1997, 144, 524-532.

26 J. Kawamura, Solid State Ionics, 2004, 175, 273-276.

27 Y.-C. Perng, J. Cho, S. Y. Sun, D. Membreno, N. Cirigliano, B. Dunn and J. P. Chang, J. Mater. Chem. A, 2014, 2, 9566.

28 S. Kim, M. Hirayama, S. Taminato and R. Kanno, Dalton Trans., 2013, 42, 13112-13117.

29 J. Reinacher, S. Berendts and J. Janek, Solid State Ionics, 2014, 258, 1-7.

30 K. Tadanaga, H. Egawa, A. Hayashi, M. Tatsumisago, J. Mosa, M. Aparicio and A. Duran, J. Power Sources, 2015, 273, 844-847.

31 S. Stramare, V. Thangadurai and W. Weppner, Chem. Mater., 2003, 15, 3974-3990. 
32 Y. J. Shan, L. Chen, Y. Inaguma, M. Itoh and T. Nakamura, J. Power Sources, 1995, 54, 397-402.

33 Y. Inaguma, C. Liquan, M. Itoh, T. Nakamura, T. Uchida, H. Ikuta and M. Wakihara, Solid State Commun., 1993, 86, 689-693.

34 E. J. van den Ham, N. Peys, C. De Dobbelaere, J. D'Haen, F. Mattelaer, C. Detavernier, P. H. L. Notten, A. Hardy and M. K. Van Bael, J. Sol-Gel Sci. Technol., 2015, 73, 536-543.

35 S. Furusawa, H. Tabuchi, T. Sugiyama, S. Tao and J. Irvine, Solid State Ionics, 2005, 176, 553-558.

36 K. Kiaoka, H. Kozuka, T. Hashimoto and T. Yoko, J. Mater. Sci., 1997, 32, 2063-2070.

37 C. Delmas, A. Nadiri and J. L. Soubeyroux, Solid State Ionics, 1988, 28-30, 419-423.

38 K. Takada, M. Tansho, I. Yanase, T. Inada, A. Kajiyama, M. Kouguchi, S. Kondo and M. Watanabe, Solid State Ionics, 2001, 139, 241-247.

39 L. Baggetto, J. F. M. Oudenhoven, T. Van Dongen, J. H. Klootwijk, M. Mulder, R. A. H. Niessen, M. De Croon and P. H. L. Notten, J. Power Sources, 2009, 189, 402-410.

40 N. C. Saha and H. G. Tompkins, J. Appl. Phys., 1992, 72, 3072.

41 K. Nishio and T. Tsuchiya, Sol. Energy Mater. Sol. Cells, 2001, 68, 279-293.

42 L. Muresan, E. J. Popovici, A. R. Tomsa and E. Indrea, J. Optoelectron. Adv. Mater., 2008, 10, 2261-2264.

43 D. B. Kokh, A. B. Alekseyev and R. J. Buenker, J. Chem. Phys., 2004, 120, 11549-11556.

44 O. J. Klejnot, Inorg. Chem., 1965, 4, 1668-1670.

45 K. Arbi, S. Mandal, J. M. Rojo and J. Sanz, Chem. Mater., 2002, 14, 1091-1097.

46 M. I. Bernal-Uruchurtu, G. Kerenskaya and K. C. Janda, Int. Rev. Phys. Chem., 2009, 28, 223-265.

47 S.-H. Wang, T.-C. Chou and C.-C. Liu, Sens. Actuators, B, 2003, 94, 343-351.

48 G. Leftheriotis, S. Papaefthimiou, P. Yianoulis and A. Siokou, Thin Solid Films, 2001, 384, 298-306.

49 L. Berggren, J. C. Jonsson and G. a. Niklasson, J. Appl. Phys., 2007, 102, 083538.

50 D. Dini and F. Decker, J. Appl. Electrochem., 1996, 26, 647653.
51 S. Darmawi, S. Burkhardt, T. Leichtweiss, D. a. Weber, S. Wenzel, J. Janek, M. T. Elm and P. J. Klar, Phys. Chem. Chem. Phys., 2015, 17, 15903-15911.

52 X. He and H. Liu, Catal. Today, 2014, 233, 133-139.

53 M. Kaufhold and M. El-Chahawi, US Pat., 5,527,969, Huels Aktiengesellschaft, 1996.

54 M. R. Capeletti, L. Balzano, G. de la Puente, M. Laborde and U. Sedran, Appl. Catal., A, 2000, 198, L1-L4.

55 J. Livage and D. Ganguli, Sol. Energy Mater. Sol. Cells, 2001, 68, 365-381.

56 H. Ryu, K. Park, I. Kim, K. Hong, W. Lee and J. Park, Synthesis and characterization of $\mathrm{WO}_{3}$ nanopowders and their electrical properties, 2003, vol. 42, pp. 727-730.

57 T. Vogt, P. M. Woodward and B. A. Hunter, J. Solid State Chem., 1999, 144, 209-215.

58 S. Pokhrel, J. Birkenstock, A. Dianat, J. Zimmermann, M. Schowalter, A. Rosenauer, L. C. Ciacchi and L. Mädler, CrystEngComm, 2015, 17, 6985-6998.

59 R. W. Schwartz, T. Schneller and R. Waser, C. R. Chim., 2004, 7, 433-461.

60 D. Perednis and L. J. Gauckler, J. Electroceram., 2005, 14, 103-111.

61 M. Majumder, C. Rendall, M. Li, N. Behabtu, J. A. Eukel, R. H. Hauge, H. K. Schmidt and M. Pasquali, Chem. Eng. Sci., 2010, 65, 2000-2008.

62 A. Temmink, O. Anderson and K. Bange, Thin Solid Films, 1990, 192, 211-218.

63 G. Hollinger and T. M. Duc, Phys. Rev. Lett., 1976, 37, 15641567.

64 C. Cantalini, H. T. Sum, M. Faccio, M. Pelino, S. Santucci, L. Lozzi and M. Passacantando, Sens. Actuators, B, 1996, 31, 81-87.

65 T. J. Driscoll, L. D. McCormick and W. C. Lederer, Surf. Sci., 1987, 187, 539-558.

66 P. L. Hagedoorn, J. R. Freije and W. R. Hagen, FEBS Lett., 1999, 462, 66-70.

67 Z. He, Z. Wang, F. Wu, H. Guo, X. Li and X. Xiong, J. Alloys Compd., 2012, 540, 39-45.

68 Q. Zhong, J. R. Dahn and K. Colbow, Phys. Rev. B: Condens. Matter Mater. Phys., 1992, 46, 2554-2560.

69 K. H. Cheng and M. S. Whittingham, Solid State Ionics, 1980, 1, 151-161. 